\title{
FAKTOR-FAKTOR YANG MEMPENGARUHI PRODUKTIVITAS USAHA TERNAK SAPI BALI PADA PETERNAK TRANSMIGRAN DAN NON TRANSMIGRAN DI PULAU KABAENA KABUPATEN BOMBANA
}

\author{
Andri Ananta ${ }^{1}$, Harapin Hafid ${ }^{2}$, La Ode Arsad Sani ${ }^{2}$ \\ ${ }^{1)}$ Alumnus Jurusan Peternakan Fapet Unhalu \\ ${ }^{2)}$ Dosen Jurusan Peternakan Fapet Unhalu \\ "e-mail : kabaenaa@yahoo.com
}

\begin{abstract}
ABSTRAK
Pengembangan usaha ternak Sapi Bali di Kecamatan Kabaena Utara perlu ditingkatkan dengan pola manajemen pemeliharaan yang baik dan terarah. Data faktor-faktor yang mempengaruhinya belum diketahui secara pasti. Oleh karena itu perlu penelitian dengan tujuan mengetahui produktivitas usaha ternak Sapi Bali baik peternak transmigran maupun non transmigran di Pulau Kabaena serta faktor-faktor apa saja yang mempengaruhinya. Materi penelitian adalah peternak sapi Bali baik transmigran maupun non transmigran yang memiliki ternak sapi bali minimal 1 ekor induk yang sudah pernah melahirkan atau 1 ekor jantan umur $>2$ tahun dan minimal telah memelihara ternak selama 1 tahun. Penentuan lokasi dengan cara purposive sampling dan responden penelitian ditentukan secara simple random sampling sebanyak 60 responden, 30 peternak transmigran dan 30 peternak non transmigran. Analisis yang dugunakan adalah regresi linear berganda yang dijabarkan secara deskriptif. Hasil penelitian menunjukkan produktivitas usaha peternak non transmigran (36\%) lebih tinggi dibandingkan peternak transmigran (24\%). Hasil analisis regresi menunjukkan bahwa produktivitas usaha ternak Sapi Bali sebagai variabel dependen secara keseluruhan berpengaruh terhadap variabel independen (pengalaman, umur, tenaga kerja keluarga, pendidikan, luas lahan, jenis pekerjaan, dan asal peternak) dengan ketepatan model regresi sebesar $29,4 \%$.
\end{abstract}

Kata kunci : Produktivitas usaha, sapi bali, transmigran, non transmigran, Kabaena.

\begin{abstract}
Development of Bali cattle bussines's in North Kabaena Subdistrict need to be improved with better and more guided maintenance management. Data of factors that affect it does not known properly yet. Therefore, there is needed a research which is held to know the productivity of bali cattle breeding of either trnasmigrant or non transmigrant breeder in Kabaena Island and factors that affect it. The research material is either the transmigrant or non transmigrant bali cattle breeders that have at least 1 female cattle that has born or 1 male cattle more than 2 years old and have maintained cattle at least 1 year. The research location is determined by purposive sampling method and the research responden is determined by simple random sampling method as many as 60 respondens, consist of 30 transmigrant breeders and 30 non transmigrant breeders. Analysis which is used in this research is Bifilarly Linear Regression that is explained descriptively. The result of this research showed that bussines of non transmigrant breeder (36\%) is higher than transmigrant breeder (24\%). The result of regression analysis showed that productivity of bali cattle bussines as dependent variable had an comprehensively affect on independent variable (experience, age, family employee, education, areal wide, occupation, and the breeder origin) with accuracy of regression model is $29,4 \%$.
\end{abstract}

Key words: Productivity bussines, Bali cattle, transmigrant, non transmigrant, Kabaena.

\footnotetext{
${ }^{*)}$ Corresponding autho
} 


\section{PENDAHULUAN}

Sapi bali merupakan sapi lokal asli Indonesia yang merupakan salah satu ternak kebanggaan nasional yang diketahui mempunyai keunggulan-keunggulan yang disukai oleh peternak, sehingga pengembangannya relatif merata hampir di seluruh pelosok nusantara. Sapi bali selama ini dikenal sebagai ternak yang dipelihara secara individual dengan cara-cara tradisional. Hal ini menyebabkan perkembangan sapi bali agak lambat dan cenderung tetap, namun disisi lain teknologi pengolahan pakan untuk ternak sapi telah tersedia dan sebagian peternak telah mengaplikasikannya secara kontinyu sehingga diharapkan ternak yang dihasilkan di Sulawesi Tenggara meningkat produksi dan produktivitasnya dan mampu memenuhi permintaan pasar lokal maupun luar Sulawesi Tenggara.

Produktivitas usaha ternak yang rendah dapat terjadi karena pola manajemen pemeliharaan ternak yang masih rendah dan kurang terarah, dimana peternak belum optimal memperhatikan kualitas pakan, tata cara pemeliharaan yang dianjurkan, perkandangan, penanganan penyakit dan pemasaran. Dalam upaya peningkatan produktivitas dan mutu sapi bali perlu terobosan teknologi yang bersifat spesifik lokasi dan berwawasan lingkungan. Upaya-upaya peningkatan produktivitas telah banyak dilakukan antara lain dengan perbaikan mutu pakan (Lana dan Nitis, 1992).

Penyebaran populasi ternak sapi di Sulawesi Tenggara pada tahun 2010 mencakup dua belas wilayah kabupaten kota dengan jumlah 268.138 ekor dan 9,71\% diantaranya berada di Kabupaten Bombana sebanyak 26.047 ekor (BPS, 2011). Populasi ternak Sapi Bali di Pulau Kabaena pada tahun 2010 berjumlah 3.885 ekor $(14,92 \%)$ dari total populasi sapi potong yang ada di Kabupaten Bombana (BPS, 2011).

Penempatan penduduk asal transmigrasi di Pulau Kabaena telah berlangsung sejak tahun
1995, seiring dengan adanya program naßeonbhngunan pet menempatkan transmigran dari Jawa dan Bali di Sulawesi Tenggara. Penduduk transmigran di Pulau Kabaena ini sebagian besar berdomisili di Kecamatan Kabaena Utara yang bekerja sebagai petani dan sebagian lainnya peternak. Pada tahun 2010 jumlah penduduk Kecamatan Kabaena Utara sebanyak 3.671 jiwa yang penduduknya adalah asal transmigrasi dan penduduk non transmigrasi (BPS, 2011).

Upaya peningkatan populasi sapi bali di Kabupaten Bombana terus dilakukan dan tentunya tidak terlepas dari peranan peternak transmigran maupun non transmigran sebagai tenaga kerja keluarga yang merupakan salah satu faktor produksi usaha ternak sapi. Sejalan dengan keberadaan peternak transmigran dan non transmigran, penelitian Sani (2010) di Konawe Selatan menunjukkan bahwa produktivitas peternak sebagai tenaga kerja keluarga pada usaha ternak sapi masih relatif rendah. Usaha ternak sapi masih dianggap sebagai tabungan dan usaha sambilan setelah pekerjaan pokok sebagai petani, baik oleh peternak transmigran maupun non transmigran. Namun demikian dinyatakan pula bahwa peternak transmigran mempunyai keragaman sumber daya terbatas (pendidikan, modal, dan luas lahan garapan), akan tetapi mampu memanfaatkan sumber daya yang dimilikinya secara optimal karena didukung oleh semangat dan motivasi kerja yang relatif tinggi bila dibandingkan dengan peternak non transmigran.

usaha ternak sapi bali, baik peternak transmigran maupun non transmigran di Pulau Kabaena adalah lama usaha beternak (tahun), umur peternak (tahun), jumlah tenaga kerja terlibat (TKSP), pendidikan formal (tahun), luas lahan pertanian (ha), dan jenis pekerjaan (macam).

\section{MATERI DAN METODE}

\section{A. Waktu dan Tempat Penelitian}


Pelaksanaan penelitian ini berlangsung bulan Mei 2011, di Kecamatan Kabaena Utara Kabupaten Bombana Provinsi Sulawesi Tenggara.

\section{B. Penentuan Lokasi dan Sampel Penelitian}

Penentuan lokasi penelitian dilakukan secara purposive sampling dengan pertimbangan bahwa di Kecamatan Kabaena Utara terdapat peternak sapi bali penduduk transmigrasi dan peternak penduduk non transmigran. Penentuan responden sebagai obyek penelitian dilakukan secara simple random sampling sebanyak 60 responden, masing-masing 30 peternak transmigran dan 30 peternak non transmigran dengan menggunakan cara lot.

Obyek penelitian adalah peternak yang memelihara sapi bali dengan kriteria usaha minimal 1 ekor induk yang sudah pernah melahirkan atau 1 ekor jantan umur $\geq 2$ tahun. Peternak merupakan penduduk transmigran dan non transmigran yang berdomisili di Kecamatan Kabaena Utara yang memiliki pengalaman beternak sapi bali minimal 1 tahun.

\section{Teknik Pengumpulan Data}

Data yang dikumpulkan pada penelitian ini adalah data primer yang diperoleh dengan cara wawancara menggunakan daftar pertanyaan (kuesioner) dan pengamatan langsung di lapangan (observasi). Data sekunder adalah data yang diperoleh dari dinas serta instansi pemerintah yang terkait dengan penelitian ini.

\section{Variabel yang Diamati}

Variabel yang diamati dalam penelitian ini adalah produktivitas usaha meliputi karakteristik usaha seperti: lama usaha beternak (tahun), umur beternak (tahun), jumlah tenaga kerja terlibat (TKSP), pendidikan formal (tahun), jenis pekerjaan (jenis), dan luas lahan pertanian (ha). (2) Manajemen pemeliharaan meliputi: pola pemeliharaan ekstensif dan semi intensif, ketersediaan bibit, ketersediaan pakan dan pengendalian penyakit, sistem perkandangan, tingkat mortalitas, dan jumlah kelahiran pedet. (3) Sistem pemasaran sapi bali (harga jual dan volume penjualan).

\section{E. Analisis Data}

Data produktivitas, manajemen pemeliharaan dan sistem pemasaran usaha ternak sapi bali antara peternak transmigran dan non transmigran akan ditabulasi menjadi angkaangka persentase dan dijelaskan secara deskriptif. Faktor-faktor yang mempengaruhi produktivitas usaha ternak sapi bali antara peternak transmigran dan non transmigran ditabulasi dan dianalisis menggunakan regresi linear berganda dengan model matematis menurut Widarjono (2007)

$$
\begin{aligned}
& P=\alpha+\beta_{1} X_{1+} \beta_{2} X_{2}+\beta_{3} X_{3}+\beta_{4} X_{4}+\beta_{5} X_{5}+\beta_{6} X_{6}+\beta_{7} D_{7}+e \\
& \text { Keterangan: } \\
& P \quad=\text { Produktivitas (UT) } \\
& \alpha \quad=\text { konstanta atau intersep } \\
& \beta_{1^{-}} \beta_{7}=\text { Koefisien regresi masing-masing variabel } \\
& X_{1} \quad=\text { Lama usaha beternak (tahun) } \\
& X_{2} \quad=\text { Umur peternak (tahun) } \\
& X_{3} \quad=\text { Jumlah tenaga kerja terlibat (TKSP) } \\
& X_{4} \quad=\text { Pendidikan formal (tahun) } \\
& X_{5} \quad=\text { Luas lahan pertanian (ha) } \\
& X_{6} \quad=\text { Jenis pekerjaan (mom) } \\
& D \quad=\text { Asal peternak (dummy variabel) } \\
& \quad=1, \text { peternak transmigran } \\
& \quad=0, \text { peternak non transmigran } \\
& e \quad=\text { Tingkat kesalahan }
\end{aligned}
$$




\section{HASIL DAN PEMBAHASAN}

\section{A. Letak Geografis dan Wilayah Kabupaten Bombana}

Kabupaten Bombana memanjang dari utara ke selatan diantara $4^{0} 22^{\prime} 59,4^{\prime \prime}-5^{0} 28^{\prime} 26,7^{\prime \prime}$ Lintang selatan (sepanjang $\pm 180 \mathrm{~km}$ ) dan membentang dari barat ke timur diantara $121^{0} 27^{\prime} 46,7^{\prime \prime}-122^{0} 10^{\prime} 9,4$ " BT (sepanjang \pm 154 $\mathrm{km})$.Luas wilayah daratan Kabupaten Bombana $3.316,16 \mathrm{~km}^{2}$ atau 331.616 ha dari luas wilayah daratan Sulawesi Tenggara (BPS, 2011).

Secara administratif batas wilayah Kecamatan Kabaena Utara adalah (1) sebelah utara berbatasan dengan selat Kabaena, (2) sebelah timur berbatasan dengan Kecamatan Kabaena Tengah, (3) sebelah selatan berbatasan dengan Kecamatan Kabaena Selatan dan (4) sebalah barat berbatasan dengan Kecamatan Kabaena Barat (BPS, 2011).

\section{B. Keadaan Penduduk}

Konsentrasi penduduk yang Ktadbalpaten Bomba merata masih merupakan ciri yang paling menonjol dari penduduk di Kecamatan Kabaena Utara. Hal ini ditandai dengan besarnya perbedaan antara jumlah penduduk antar desa satu dengan yang lainnya. Untuk menempuh kesejahteraan masyarakat Kabupaten Bombana khususnya Kecamatan Kabaena Utara, pemerintah telah mendKapupaten Bombc bebagai upaya antara lain meningkatkan mutu pendidikan dan perbaikan pelayanan kesehatan (BPS, 2011).

\section{Umur Responden}

Umur responden dapat dilihat pada Tabel 1

Tabel 1. Karakteristik umur peternak sapi bali di lokasi penelitian

\begin{tabular}{ccccccc}
\hline \multirow{2}{*}{ Struktur umur (thn) } & \multicolumn{2}{c}{ Transmigran } & \multicolumn{2}{c}{ Non transmigran } & \multicolumn{2}{c}{ Jumlah } \\
\cline { 2 - 8 } & Org & $\mathbf{\%}$ & Org & \% & Org & \% \\
\hline $15-55$ & 25 & 83,33 & 28 & 93,33 & 53 & 88,33 \\
$>55$ & 5 & 16,67 & 2 & 6,67 & 7 & 11,67 \\
\hline Jumlah & $\mathbf{3 0}$ & $\mathbf{1 0 0}$ & $\mathbf{3 0}$ & $\mathbf{1 0 0}$ & $\mathbf{6 0}$ & $\mathbf{1 0 0}$ \\
\hline
\end{tabular}

Data pada Tabel 1 menunjukkan bahwa peternak transmigrasi dan peternak non transmigran berada pada golongan usia produktif sebanyak 53 orang $(88,33 \%)$. Pada daerah transmigrasi peternak yang berusia antara 15-55 tahun berjumlah 25 orang atau $83,33 \%$ sedangkan responden penduduk non transmigran berjumlah 28 orang atau $93,33 \%$. Hal ini sejalan dengan penelitian Soeharjo dan Patong (1984) dalam Hastian (2010) yang mengelompokkan usia berdasarkan kelompok produktif dan non produktif. Usia produktif berada pada kisaran 15-54 tahun dan usia 55 tahun ke atas dikategorikan usia non produktif. Usaha untuk mengembangkan ternak sapi bali relatif lebih mudah dilakukan karena rata-rata umur peternak di lokasi penelitian masih berumur produktif. Gambaran usia peternak yang umumnya produktif tersebut mengindisikan bahwa usaha ternak sapi di daerah transmigrasi maupun non transmigran di lokasi penelitian berpotensi untuk dikembangkan. Hasil penelitian ini sejalan dengan Fatati (2001) bahwa semakin muda umur seseorang, maka semakin mudah pula menerima perubahan dari luar karena petanipeternak selalu ingin mencoba sesuatu yang baru sebagai upaya untuk meningkatkan pengetahuan dan keterampilan dalam diversifikasi usahanya. Soekartawi $d k k$. (2002) menyatakan para petani yang berusia lanjut biasanya fanatik terhadap tradisi dan sulit untuk diberikan pengertian-pengertian yang dapat mengubah cara berpikir, cara kerja, dan cara hidupnya, suka bersikap apatis terhadap adanya teknologi baru. 


\section{Tingkat Pendidikan Responden}

Tabel 2. Tingkat pendidikan peternak di lokasi penelitian

\begin{tabular}{cccccccc}
\hline \multirow{2}{*}{ Pendidikan } & \multicolumn{3}{c}{ Transmigran } & \multicolumn{2}{c}{ Non transmigran } & \multicolumn{2}{c}{ Jumlah } \\
\cline { 2 - 8 } & Org & \% & Org & \% & Org & $\%$ \\
\hline SD & 24 & 80 & 10 & 33,33 & 34 & 56,67 \\
SLTP & 3 & 10 & 5 & 16,67 & 8 & 13,33 \\
SLTA & 2 & 6,67 & 14 & 46,67 & 16 & 26,67 \\
Perguruan Tinggi & 1 & 3,33 & 1 & 3,33 & 2 & 3,33 \\
\hline Jumlah & 30 & 100 & 30 & 100 & 60 & 100 \\
\hline
\end{tabular}

Tabel 2 menunjukkan bahwa tingkat pendidikan peternak baik transmigran maupun non transmigran umumnya hanya tingkat Sekolah Dasar (SD) yaitu 34 orang atau $56,67 \%$, sedangkan tingkat pendidikan yang paling rendah adalah perguruan tinggi yaitu hanya 2 orang atau $3,33 \%$. Kondisi ini dimungkinkan sebagai akibat dari kurangnya motivasi untuk sekolah, tingkat pendapatan peternak yang masih relatif rendah, jarak tempuh rumah dan sekolah setempat relatif jauh, lapangan pekerjaan yang terbatas sehingga lebih memilih untuk tidak sekolah, tetapi bekerja seadanya untuk memperoleh pendapatan dan memilih jenis pekerjaan tidak membutuhkan ketrampilan khusus. Ahmadi (2003) menyatakan dengan adanya tingkat pendidikan yang rendah menyebabkan seseorang kurang mempunyai keterampilan tertentu yang diperlukan dalam kehidupannya. Keterbatasan keterampilan/pendidikan yang dimiliki menyebabkan keterbatasan kemampuan memasuki dunia kerja.
Tingkat pendidikan responden diwilayah transmigrasi dan non transmigran Kecamatan Kabaena Utara dapat dilihat pada Tabel 2. 
Data pada Tabel 3 menunjukkan bahwa pengalaman beternak antara peternak transmigran maupun non transmigran $<5$ tahun sebanyak 26 orang $(43,33 \%)$ kemudian disusul 5-10 tahun sebanyak 22 orang $(36,67 \%)$ dan berpengalaman $>10$ tahun sebanyak 12 orang (20\%). Pengalaman peternak transmigran di lokasi penelitian secara umum lebih rendah dibandingkan pengalaman peternak non transmigran. Pengalaman beternak penduduk transmigran $50 \%$ kurang dari 5 tahun dan berpengalaman lebih dari 10 tahun hanya $13,33 \%$. Sebaliknya peternak non transmigran yang berpengalaman kurang dari 5 tahun sebanyak 36,67\% dan berpengalaman lebih dari 10 tahun mencapai 26,67\%. Hal ini menunjukkan pengalaman beternak sapi sudah cukup baik dan seharusnya akan memberikan pengaruh positif terhadap pengembangan usaha ternak sapi bali di lokasi penelitian yang didukung dengan usia peternak rata-rata masih produktif.

Temuan ini sesuai dengan pendapat Djafar (2007) bahwa semakin lama memelihara sapi maka peternak semakin berpengalaman dan realistis dalam menentukan jenis usaha ternak yang akan dipelihara, baik untuk tujuan mengharapkan pedet/pembibitan maupun untuk penggemukan. Penelitian Fauzia dan Tampubolon (1991) menyatakan bahwa pengalaman seseorang dalam berusaha tani dan ternak berpengaruh terhadap tingkat penerimaan inovasi dari luar. Soeharjo dan Patong (1984) mengelompokan tingkat pengalaman petani dan peternak disebut berpengalaman dalam usaha ternaknya apabila telah menggeluti bidang pekerjaannya selama lebih dari 10 tahun, cukup berpengalaman bila menggeluti bidang usahanya selama 5-10 tahun dan kurang berpengalaman bila baru menggeluti pekerjaannya kurang dari 5 tahun.

\section{F. Pekerjaan Utama Responden}

Jenis pekerjaan keluarga peternak di lokasi penelitian disajikan pada Tabel 4 .

Tabel 4. Pekerjaan utama peternak di lokasi penelitian

\begin{tabular}{cccccccc}
\hline \multirow{2}{*}{ Jenis pekerjaan } & \multicolumn{2}{c}{ Transmigran } & \multicolumn{2}{c}{ Non transmigran } & \multicolumn{2}{c}{ Jumlah } \\
\cline { 2 - 8 } & Org & \% & Org & \% & Org & \% \\
\hline Petani & 23 & 76,67 & 11 & 36,67 & 34 & 56,67 \\
Peternak & 4 & 13,33 & 5 & 16,67 & 9 & 15,00 \\
Pegawai swasta & 1 & 3,33 & 5 & 16,67 & 6 & 10,00 \\
PNS & 1 & 3,33 & 1 & 3,33 & 2 & 3,33 \\
Nelayan & 1 & 3,33 & 8 & 26,67 & 9 & 15,00 \\
\hline Jumlah & 30 & 100 & 30 & 100 & 60 & 100 \\
\hline
\end{tabular}

masing 9 orang $(15 \%)$, pegawai swasta sebanyak 6 orang $(10 \%)$, dan yang terakhir sebagai PNS sebanyak 2 orang $(3,33 \%)$. Jenis pekerjaan utama sebagai peternak antara peternak transmigran maupun non transmigran masing-masing hanya $13,3 \%$ dan $16,67 \%$. Hal ini menunjukkan bahwa beternak sapi bali merupakan usaha sambilan yang berfungsi sebagai tabungan untuk keperluan yang sifatnya mendadak, seperti membiayai sekolah Datakpada Tabel 4 kesehatan, acara adat, dan yang lainnya. Hal ini sesuai dengan pendapat Tulle (2005) bahwa: (1) sebagai usaha sambilan dengan pendapatan dari ternak < 30\%, (2) sebagai cabang usaha dengan pendapaatan dari ternak sebesar 30-70\%, (3) sebagai usaha pokok dengan pendapatan dari ternak 70-100\% dan (4) sebagai usaha industri dengan pendapatan $100 \%$ dari usaha ternak. 


\section{G. Jumlah Tenaga Kerja Keluarga dan Tingkat Keterlibatannya}

untuk lebih giat berusaha memenuhi kebutuhan seluruh anggota keluarga yang menjadi tanggung jawabnya. Berdasarkan data yang diperoleh di lokasi penelitian baik peternak transmigran maupun non transmigran, rata-rata anggota keluarga 5 orang $(8,33 \%)$ sedangkan yang terlibat dalam mengurus ternak rata-rata 2 orang $(3,33 \%)$, hal ini menyebabkan usaha peternakan lambat meningkatnya karena kurang terlibatnya sebagian besar anggota keluarga. Peternak transmigran rata-rata anggota keluarganya 4 orang $(13,33 \%)$, yang terlibat mengurus ternak sapi rata-rata hanya 2 orang $(6,67 \%)$ sedangkan peternak non transwhügndaah tenaga ker rata-rata anggota keluarganya 5 orang $(16,67 \%)$, yang terlibat pada pemeliharaan sapi rata-rata 1 orang $(3,33 \%)$. Bila dibandingkan antara keduanya, maka anggota keluarga peternak transmigran lebih tinggi tingkat keterlibatannya mengurus ternak sapi dibandingkan peternak non transmigran.

\section{H. Sumber Bibit, Sistem Perkandangan dan Tujuan Pemeliharaan}

Tabel 5. Manajemen pemeliharaan ternak sapi bali oleh peternak di lokasi penelitian

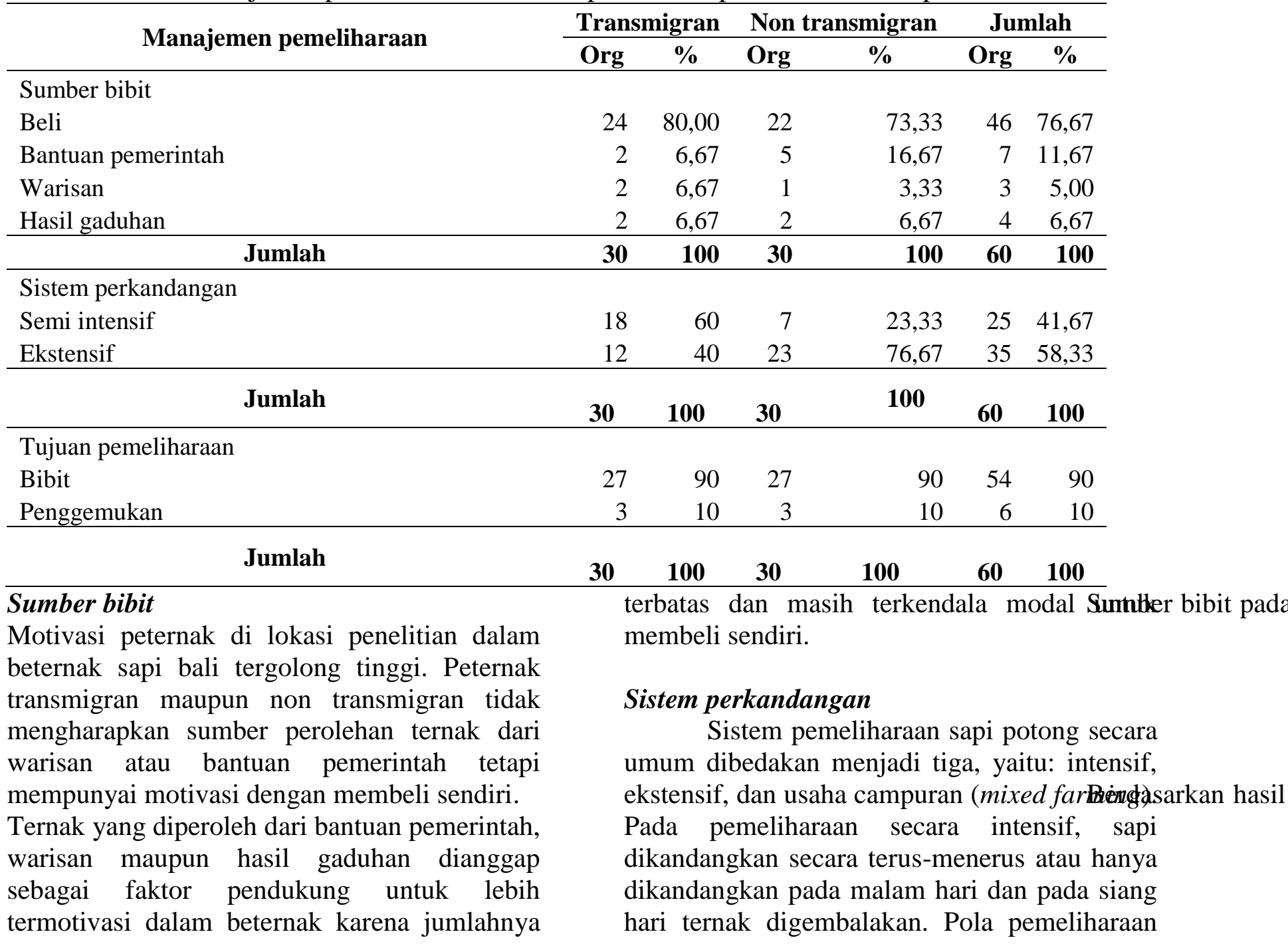


sapi secara intensif banyak dilakukan petanipeternak di Jawa, Madura, dan Bali. Pada pemeliharaan ekstensif, ternak dipelihara di padang penggembalaan dengan pola pertanian menetap atau di hutan. Pola tersebut banyak dilakukan peternak di Nusa Tenggara Timur, Kalimantan, dan Sulawesi (Sugeng, 2006). Berdasarkan kedua pola pemeliharaan tersebut, sebagian besar merupakan usaha ternak rakyat dengan ciri skala usaha rumah tangga dan kepemilikan ternak relatif sedikit, menggunakan teknologi sederhana, bersifat pada karya, dan berbasis azas organisasi kekeluargaan (Yusdja dan Ilham, 2004).

Pada Tabel 5 menunjukkan bahwa sistem pemeliharaan ternak sapi di daerah transmigran maupun non transmigran yang menggunakan sistem semi intensif sebanyak 25 orang $(41,67 \%)$ sedangkan pemeliharaan sistem ekstensif sebanyak 35 orang $(58,33 \%)$. Ternak sapi yang dipelihara oleh peternak transmigran pada umumnya dikombinasikan (semi intensif) sebanyak $60 \%$ yaitu pada pagi hari ternak sapi digembalakan di sawah atau dilepas di padang penggembalaan dan pada malam hari dikandangkan karena banyaknya gangguan keamanan dari luar seperti pencurian atau binatang buas, sebaliknya $40 \%$ sisanya menggunakan sistem ekstensif. Sedangkan peternak non transmigran, 23,33\% memelihara ternak sapi dengan sistem semi-intensif dan $76,67 \%$ dengan sistem ekstensif. Hal ini menunjukkan bahwa manajemen pemeliharaan ternak sapi di lokasi penelitian masih lebih baik peternak transmigran dibandingkan peternak non transmigran.

\section{Tujuan Pemeliharaan}

menunjukkan bahwa kedua kelompok masyarakat ini mempunyai motivasi ataupun kemauan yang sama untuk beternak sapi, yaitu memelihara sapi untuk mengharapkan anak/pedet. Motivasi ini dimungkinkan karena potensi pemasarn ternak sapi lebih menjanjikan dimasa mendatang disamping pertimbangan jangka panjang atau tabungan jika ada keperluan mendesak karena sistim pembibitan memungkinkan jumlah ternak akan bertambah, sebaliknya jika usaha penggemukan orientasinya hanya untuk dijual sebagai tambahan pendapatan.

\section{Pakan}

Pemberian pakan ternak belum dilakukan secara optimal karena ternak sebagian besar hanya diberikan pakan hijauan dengan cara menggembalakan untuk merumput sendiri dan hanya sebagian kecil (transmigran) yang mencari pakan untuk ternaknya. Biasanya kualitas rumput yang diberikan tersebut relatif rendah, karena pemeliharaan rumput-rumputan hijauan makanan ternak secara khusus masih sangat terbatas (Abidin dan Simanjuntak, 1997).

Jenis pakan ternak yang dimanfaatkan peternak di lokasi penelitian disajikan pada Tabel 6.

Tabel 6. Jenis pakan ternak sapi di lokasi penelitian

\begin{tabular}{lcccccc}
\hline \multirow{2}{*}{ Jenis Pakan } & \multicolumn{2}{c}{ Tranmigrasi } & \multicolumn{2}{c}{ Non transmigran } & \multicolumn{2}{c}{ Jumlah } \\
\cline { 2 - 8 } & Org & $\mathbf{\%}$ & Org & \% & Org & $\%$ \\
\hline RA + LP & 18 & 60,00 & 27 & 90,00 & 45 & 75,00 \\
RA + GM + LN & 7 & 23,33 & 0 & 0,00 & 7 & 11,67 \\
RA + DD & 5 & 16,67 & 3 & 10,00 & 8 & 13,33 \\
\hline \multicolumn{1}{c}{ Jumlah } & $\mathbf{3 0}$ & $\mathbf{1 0 0}$ & $\mathbf{3 0}$ & $\mathbf{1 0 0}$ & $\mathbf{6 0}$ & $\mathbf{1 0 0}$ \\
\hline
\end{tabular}


Tabel 6 menunjukkan bahwa pakan yang banyak digunakan peternak di daerah transmigrasi maupun non transmigran adalah rumput alam dan limbah pertanian sebanyak 45 orang $(75 \%)$ disusul peternak yang memberikan pakan kombinasi rumput alam dan dedak sebanyak 8 orang $(13,33 \%)$, dan kombinasi rumput alam, gamal, dan lantoro sebanyak 7 orang $(11,67 \%)$. Pada daerah transmigrasi yang memberikan rumput alam dan limbah pertanian sebanyak 18 orang $(60 \%)$ dan pakan yang paling sedikit diberikan kepada ternak adalah kombinasi rumput alam dan dedak sebanyak 5 orang $(16,67 \%)$. Sedangkan peternak non transmigran hampir keseluruhan masih mengandalkan hijauan makanan ternak untuk ternak sapi yang mereka pelihara adalah rumput alam atau rumput yang tumbuh liar dan limbah pertanian. Hasil penelitian menunjukkan bahwa 90\% peternal non transmigran masih memberikan pakan hijauan dari rumput alam atau rumput yang tumbuh liar dan limbah pertanian, hanya $10 \%$ yang menggunakan rumput alam dan dedak.

Berdasarkan hasil wawancara dengan peternak di daerah transmigrasi menyatakan bahwa ketersediaan pakan ternak pada musim kemarau dan musim tanam relatif susah diperoleh. Pada musim tersebut para peternak mencari pakan untuk ternaknya dari hutanhutan disekitar pemukiman penduduk dan pengambilan pakan dilakukan pada pagi hari dan hanya ditujukan untuk memenuhi kebutuhan pakan sehari. Proses ini berlangsung secara terus-menerus dimana peternak tidak menyediakan pakan ternak untuk jangka waktu yang lama.

\section{J. Penyakit dan Cara Penanggulangannya 1. Penyakit}

Keberhasilan peternakan sapi tidak hanya terletak pada usaha pengembangan jumlah ternak sapi yang dipelihara, namun juga pada pengawasan dan pencegahan penyakit sehingga kesehatan ternak sapi tetap terjaga. Fatah (2008) menyatakan bahwa usaha pencegahan penyakit dapat dilakukan untuk menjaga kesehatan ternak adalah ternak yang sakit dipisahkan dengan ternak yang sehat dan segera dilakukan pengobatan serta memeriksa kesehatan ternak secara teratur dan dilakukan vaksinasi sesuai petunjuk. Jenis penyakit ternak sapi di lokasi penelitian dapat dilihat pada Tabel 7

Tabel 7. Jenis penyakit ternak sapi bali di lokasi penelitian

\begin{tabular}{ccccccc}
\hline \multirow{2}{*}{ Jenis penyakit } & \multicolumn{2}{c}{ Transmigran } & \multicolumn{2}{c}{ Non transmigran } & \multicolumn{2}{c}{ Jumlah } \\
\cline { 2 - 8 } & Org & $\mathbf{\%}$ & Org & \% & Org & \% \\
\hline MT+CA+LPH + GN & 29 & 96,67 & 21 & 70,00 & 50 & 83,33 \\
BS + MN + GT + BK & 1 & 3,33 & 9 & 30,00 & 10 & 16,67 \\
\hline Jumlah & $\mathbf{3 0}$ & $\mathbf{1 0 0}$ & $\mathbf{3 0}$ & $\mathbf{1 0 0}$ & $\mathbf{6 0}$ & $\mathbf{1 0 0}$ \\
\hline
\end{tabular}

$\begin{array}{ll}\text { Keterangan: } \\ \text { MT } & \text { : Mata } \\ \text { CA } & \text { : Cacingan } \\ \text { LPH } & \text { : Lumpuh } \\ \text { GT } & \text { : Gatal }\end{array}$

Berdasarkan hasil wawancara dengan responden di lokasi penelitian, bahwa penyakit yang menyerang ternak sapi adalah mata, cacingan, lumpuh, gondok, bisul, mencret, gatal, dan berkudis. Namun penyakit yang

$\begin{array}{ll}\text { BS } & : \text { Bisul } \\ \text { BK } & : \text { Berkudis } \\ \text { GN } & : \text { Gondok } \\ \text { MN } & \text { : Mencret }\end{array}$

paling sering menyerang ternak adalah penyakit mata, cacingan, lumpuh, dan gondok, antara peternak transmigran maupun non transmigran penyakit ini yang mendominasi yakni $(83,33 \%)$ disusul penyakit-penyakit yang lain diantaranya 
penyakit bisul, mencret, gatal, dan berkudis sebanyak $16,67 \%$. Pada ternak yang terserang penyakit biasa nampak terlihat langsung dengan kondisi fisiknya seperti mata berair, badan kurus, malas makan dan malas beraktivitas.

\section{Pengendalian penyakit}

Usaha pencegahan yang dilakukan untuk menjaga kesehatan sapi adalah: (1) menjaga

Tabel 8. Pengendalian penyakit ternak sapi bali di lokasi penelitian

\begin{tabular}{lrrrrrrr}
\hline \multirow{2}{*}{ Pengobatan penyakit } & \multicolumn{2}{c}{ Transmigran } & \multicolumn{2}{c}{ Non transmigran } & \multicolumn{2}{c}{ Jumlah } \\
\cline { 2 - 8 } & Org & \% & Org & \multicolumn{1}{c}{$\%$} & Org & \multicolumn{1}{c}{} \\
\hline GRM & 10 & 33,33 & 11 & 36,67 & 21 & 35,00 \\
MTH+GRM & 5 & 16,67 & 2 & 6,67 & 7 & 11,67 \\
GRM+TM+CB & 3 & 10,00 & 0 & 0,00 & 3 & 5,00 \\
OBK & 5 & 16,67 & 14 & 46,67 & 19 & 31,67 \\
GRM+AJM+AT & 4 & 13,33 & 3 & 10,00 & 7 & 11,67 \\
PPB & 3 & 10,00 & 0 & 0,00 & 3 & 5,00 \\
\hline \multicolumn{1}{c}{ Jumlah } & $\mathbf{3 0}$ & $\mathbf{1 0 0}$ & $\mathbf{3 0}$ & $\mathbf{1 0 0}$ & $\mathbf{6 0}$ & $\mathbf{1 0 0}$ \\
\hline
\end{tabular}

\section{Keterangan:}

$\begin{array}{ll}\text { MTH } & \text { : Minyak tanah } \\ \text { GRM } & : \text { Garam } \\ \text { OBK } & : \text { Obat Kimiawi } \\ \text { TM } & : \text { Tembakau }\end{array}$

$\begin{array}{ll}\text { AJM } & \text { : Air daun jambu batu } \\ \text { AT } & \text { : Air teh } \\ \text { PBB } & \text { : Pemberian pakan berkualitas } \\ \text { CB } & \text { :Cabe }\end{array}$

Secara umum peternak di lokasi penelitian telah menggunakan obat tradisional dalam menanggulangi penyakit ternak sapi di antaranya minyak tanah, garam, tembakau, cabe, air daun jambu batu, air teh, pemberian pakan berkualitas dan obat kimiawi. Namun dari sekian banyak obat tradisional yang digunakan untuk mengobati penyakit ternak sapi di lokasi penelitian, garam paling banyak digunakan peternak yakni sebanyak 21 orang (35\%), obat tradisional ini bertujuan untuk menyembuhkan penyakit mata. Sedangkan pemberian obat tradisional lain seperti minyak tanah dan kombinasi garam, air daun jambu batu, dan air teh; garam, asam, dan obat kimiawi juga untuk mengobati penyakit mata dan penyakit lain. Kombinasi garam, tambakau dan cabe adalah obat yang paling sedikit kebersihan kandang serta peralatannya, termasuk memandikan sapi, (2) sapi yang sakit dipisahkan dengan sapi yang sehat dan segera dilakukan pengobatan, (3) mengusahakan lantai kandang selalu kering, (4) memeriksa kesehatan sapi secara teratur dan dilakukan vaksinasi sesuai petunjuk (Fatah, 2008). Pengendalian penyakit ternak sapi di lokasi penelitianDlanlagnt upaya pen dilihat pada Tabel 8 . 
Tabel 9. Rata-rata luas lahan peternak transmigran dan non transmigran di lokasi penelitian

\begin{tabular}{|c|c|c|c|c|c|c|}
\hline \multirow{2}{*}{$\begin{array}{c}\text { Struktur } \\
\text { kepemilikan lahan }\end{array}$} & \multicolumn{2}{|c|}{ Transmigran } & \multicolumn{2}{|c|}{ Non transmigran } & \multicolumn{2}{|c|}{ Jumlah } \\
\hline & ha $\mathrm{KK}^{-1}$ & $\%$ & ha $\mathrm{KK}^{-1}$ & $\%$ & ha $\mathrm{KK}^{-1}$ & $\%$ \\
\hline Jambu mente & 0,70 & 45,11 & 1,83 & 83,97 & 2,53 & 67,83 \\
\hline Kelapa & 0,06 & 3,87 & 0,17 & 7,63 & 0,23 & 6,07 \\
\hline Jati & 0,18 & 11,28 & 0,18 & 8,40 & 0,36 & 9,59 \\
\hline Sayuran & 0,17 & 10,96 & 0 & 0 & 0,17 & 4,55 \\
\hline Padi sawah & 0,4 & 25,78 & 0 & 0 & 0,40 & 10,71 \\
\hline Padi lading & 0,02 & 1,07 & 0 & 0 & 0,02 & 0,45 \\
\hline Coklat & 0,03 & 1,93 & 0 & 0 & 0,03 & 0,80 \\
\hline Jumlah lahan diolah & 1,55 & 100 & 2,18 & 100 & 3,74 & 100 \\
\hline Rata-rata & 0,22 & & $\mathbf{0 , 3 1}$ & & $\mathbf{0 , 5 3}$ & \\
\hline Tidak diolah & 2,03 & & 1,92 & & 3,95 & \\
\hline
\end{tabular}

Berdasarkan data pada Tabel 9 terlihat peternak transmigran maupun non transmigran kebanyakan menanam jambu mete dengan ratarata luas lahan 2,53 ha $\mathrm{KK}^{-1}$ atau rata-rata $4,22 \%$, karena kurang suburnya tanah untuk usaha tani lain serta masih memiliki lahan yang belum diolah rata-rata 3,95 ha $\mathrm{KK}^{-1}$. Antara dua peternak ini yang paling produktif dalam mengelola lahannya adalah peternak non transmigran yakni mempunyai lahan yang belum diolah rata-rata luas lahan 1,92 ha $\mathrm{KK}^{-1}$ sedangkan peternak transmigran rata-rata luas lahan yang belum terolah adalah 2,03 ha $\mathrm{KK}^{-1}$ jadi total lahan yang belum terolah antara dua peternak ini rata-rata luas lahan 3,95 ha $\mathrm{KK}^{-1}$. Peternak yang miliki lahan luas seharusnya tingkat kepemilikan ternaknya relatif tinggi dibandingkan dengan peternak yang memiliki lahan yang sempit, namun pada kenyataannya di lokasi penelitian tidak semuanya yang memiliki lahan luas banyak pula ternaknya, hanya sebagian saja. Salah satu faktor yang mungkin menyebabkan adanya peluang lebih besar bagi peternak yang memiliki lahan luas untuk mengembangkan usaha ternaknya adalah dia dapat menanam hijauan pakan ternak yang berkualitas sehingga memungkinkan dapat memperoleh pandapatan yang lebih besar dari peternak yang memiliki lahan yang sempit.

Luas lahan merupakan faktor produksi yang sangat penting dalam pengelolaan usahatani, karena menentukan besar kecilnya usaha, mempengaruhi jumlah penggunaan faktor produksi lain dan pada akhirnya menentukkan pula tingkat produksi dan pendapatan petani. Menurut Hernanto (1996), ada tiga golongan petani berdasarkan berdasarkan luas lahan garapan sempit $(<0,5$ ha), luas lahan garapan sedang (0,5-2) dan luas lahan garapan luas (> 2 ha). Minimnya luas lahan yang dimiliki petani-peternak transmigran dan sebagian peternak non transmigrann disebabkan oleh kepadatan penduduk yang semakin meningkat setiap tahunnya sehingga usaha pengembangan peternakan di lokasi penelitian tidak berkembang.

\section{Pemilikan Ternak}

Jumlah pemilikan ternak dapat dilihat pada Tabel 10. 
Tabel 10. Pemilikan ternak sapi bali berdasarkan struktur populasi pada peternak transmigran dan non transmigran di lokasi penelitian

\begin{tabular}{ccccccccccc}
\hline \multirow{2}{*}{$\begin{array}{c}\text { Struktur populasi } \\
\text { (umur) }\end{array}$} & \multicolumn{3}{c}{ Transmigran } & \multicolumn{3}{c}{ Non transmigran } & \multicolumn{3}{c}{ Jumlah } \\
\cline { 2 - 11 } & Ekor & $\mathbf{\%}$ & UT & Ekor & \% & UT & Ekor & \% & UT \\
\hline Betina $>$ 2 tahun & 94 & 41,05 & 94 & 161 & 44,48 & 161 & 255 & 43,15 & 255 \\
Jantan > 2 tahun & 32 & 13,97 & 32 & 33 & 9,12 & 33 & 65 & 11,00 & 65 \\
Betina 1-2 tahun & 39 & 17,03 & 19,5 & 51 & 14,09 & 25,5 & 90 & 15,23 & 45 \\
Jantan 1-2 tahun & 21 & 9,17 & 10,5 & 22 & 6,08 & 11 & 43 & 7,28 & 21,5 \\
Betina < 1 tahun & 19 & 8,30 & 4,75 & 54 & 14,92 & 13,5 & 73 & 12,35 & 18,25 \\
Jantan < 1 tahun & 24 & 10,48 & 6 & 41 & 11,33 & 10,25 & 65 & 11,00 & 16,25 \\
\hline \multicolumn{1}{c}{ Jumlah } & $\mathbf{2 2 9}$ & $\mathbf{1 0 0}$ & $\mathbf{1 6 6 , 8}$ & $\mathbf{3 6 2}$ & $\mathbf{1 0 0}$ & $\mathbf{2 5 4 , 3}$ & $\mathbf{5 9 1}$ & $\mathbf{1 0 0}$ & $\mathbf{4 2 1}$ \\
\hline \multicolumn{1}{c}{ Rata-rata } & $\mathbf{7 , 6 3}$ & & $\mathbf{5 . 5 6}$ & $\mathbf{1 2 , 1}$ & & $\mathbf{8 , 4 7}$ & $\mathbf{9 , 8 5}$ & & $\mathbf{7 , 0 1}$ \\
\hline Induk beranak & 47 & & & 102 & & & 149 & & \\
Jumlah sapi mati & 31 & & & 26 & & & 57 & & \\
\hline
\end{tabular}

Data pada Tabel 10 menunjukkan bahwa peternak transmigran maupun non transmigran mempunyai pemilikan ternak sapi betina diatas 2 tahun sebanyak 255 ekor (255 UT) dan jantan diatas 2 tahun sebanyak 65 ekor (65 UT) yang disusul betina umur 1-2 tahun sebanyak 90 ekor (45 UT), jantan umur 1-2 tahun sebanyak 43 ekor (21,5 UT), betina dibawah 1 tahun sebanyak 73 ekor (18,25 UT), dan jantan dibawah 1 tahun sebanyak 65 ekor $(16,25$ UT) dari total kepemilikan sebanyak 591 ekor (421 UT). Peternak transmigran memiliki ternak sebanyak 229 ekor, sedangkan peternak non transmigran pemilikan ternak sebanyak 362 ekor. Rata-rata kepemilikan ternak sapi bali menunjukkan bahwa peternak non transmigran lebih banyak yakni 8,47 UT dan sebaliknya peternak transmigran hanya 5,56 UT. Kepemilikan sapi induk masih dominan dipelihara dibandingkan dengan struktur populasi lainnya. Hal ini terjadi dimungkinkan karena peternak di lokasi penelitian lebih termotivasi memelihara sapi dengan cara dibibitkan atau memperoleh pedet sehingga peternak enggan menjual ternak induk atau betina karena diinginkan sebagai calon induk dan mereka lebih senang menjual ternak jantan saja. Produktivitas usaha ternak sapi bali antara peternak transmigran dan peternak non transmigran dapat dilihat pada Gambar 1.

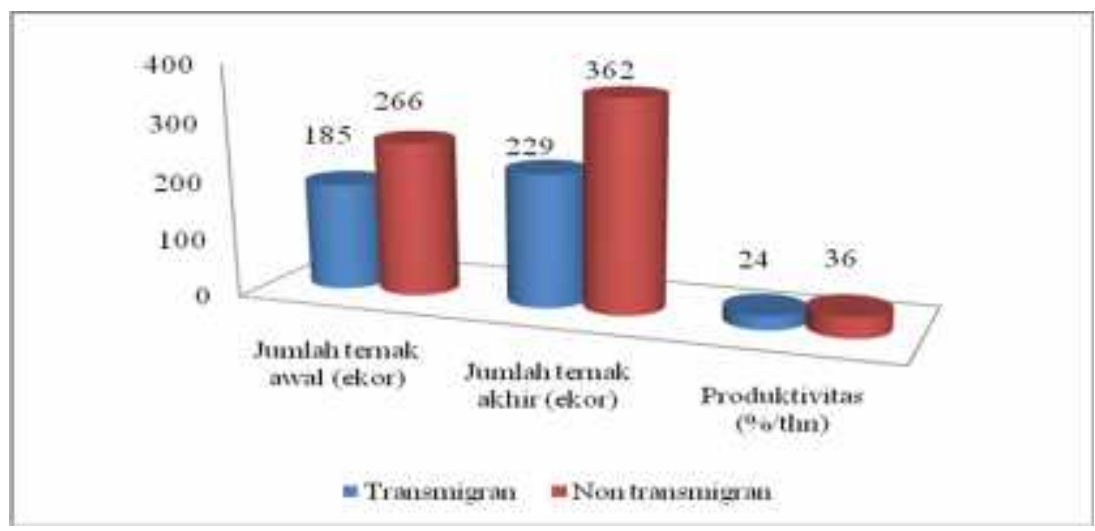

Gambar 1. Usaha kepemilikan ternak sapi bali antara peternak transmigran dan peternak non transmigran di lokasi penelitian satu tahun terakhir (Mei 2010 - Mei 2011 
Pada Gambar 1 memperlihatkan kepemilikan sapi bali untuk satu tahun terakhir oleh peternak non transmigran lebih tinggi dibandingkan dengan peternak transmigran. Peternak non transmigran mempunyai kepemilikan awal sebanyak 266 ekor dan kepemilikan akhir sebanyak 362 ekor dengan peningkatan populasi sebanyak $36 \%$ pertahun sedangkan peternak transmigran mempunyai kepemilikan awal sebanyak 185 ekor dan kepemilikan akhir sebanyak 229 ekor dengan peningkatan populasi hanya sebesar $24 \%$ pertahun. Hal ini menunjukkan bahwa produktivitas usaha peternak non transmigran di lokasi penelitian lebih tinggi dibandingkan dengan peternak transmigran. Peternak non transmigran mempunyai kecukupan modal serta kepemilikan lahan cukup luas untuk menunjang usaha ternaknya. Hardjosubroto (1992) menyatakan produktivitas ternak dipengaruhi oleh komposisi ternak berdasarkan umur, jenis kelamin, kelahiran, kematian, dan lamanya ternak dalam pembiakan. Produktivitas usaha ternak yang rendah disebabkan karena pola manajemen pemeliharaan ternak yang masih rendah dimana peternak belum optimal memperhatikan kualitas pakan, tata cara pemeliharaan yang dianjurkan, perkandangan, penanganan penyakit dan pemasaran. Upaya peningkatan produktivitas dan mutu sapi bali perlu terobosan teknologi yang bersifat spesifik lokasi dan berwawasan lingkungan.

\section{Pemasaran Ternak}

Pemasaran ternak merupakan tujuan akhir dari salah satu usaha peternakan dan juga menentukan untung ruginya suatu usaha.

Berdasarkan hasil wawancara dengan responden di lokasi penelitian diperoleh informasi bahwa pemasaran ternak sapi bali ditingkat peternak relatif baik, walaupun peternak tidak pernah langsung menjual ternaknya ke pedagang pasar melainkan ke tengkulak (pedagang perantara). Harga jual ternak untuk sapi jantan dewasa umur 2 tahun kebawah berkisar antara Rp. 4.000.000 - Rp.
5.000.000 per ekor dan untuk sapi betina dewasa yang belum melahirkan dibawah 2 tahun berkisar antara Rp.3.500.000 sampai Rp.4.500.000 per ekor, sedangkan harga jual untuk sapi yang sudah melahirkan atau sapi induk diatas 2 tahun berkisar antara $\mathrm{Rp}$. 7.000.000 sampai Rp.7.500.000 per ekor. Hal ini dapat dilihat bahwa harga jual ternak sapi induk diatas 2 tahun atau yang sudah pernah melahirkan lebih tinggi dibandingkan dengan harga jual ternak sapi jantan umur 2 tahun kebawah dan betina dewasa yang belum melahirkan. Penelitian ini sejalan dengan Sukma (2011) mengatakan bahwa harga jual sapi jantan dewasa dan sapi muda lebih rendah dibandingkan dengan harga jual sapi induk.

Harga jual ternak sapi di lokasi penelitian cendrung meningkat pada saat menjelang hari raya Idul Adha dan acara-acara pesta perkawinan yang mencapai Rp8.000.000/ekor, namun sebaliknya ketika kebutuhan sangat mendesak dan harus menjual ternaknya seperti kebutuhan biaya sekolah, hajatan dan lain-lain maka peternak tidak mempunyai pilihan untuk tawar-menawar harga yang kuat sehingga peternak harus menjual ternaknya dengan harga yang relatif rendah hingga sebesar Rp 2.500.000-Rp. 3.000.000 yang sapi umur kurang dari 2 tahun. Posisi tawar petani lemah sehingga menjadi peluang bagi pembeli untuk mengambil keuntungan yang besar. Kondisi ini sejalan dengan penelitian Hartoyo (2005) bahwa penjualan ternak ruminansia berlangsung secara dinamis, harga selalu berfluktuatif. Kondisi ini berkaitan langsung dengan permintaan dan penawaran. Harga tinggi biasa terjadi pada saat menjelang hari raya Idul Adha, namun sebaliknya ketika kebutuhan sangat mendesak dan harus menjual ternak seperti kebutuhan biaya sekolah, hajatan dan lain-lain. 


\section{KESIMPULAN}

1. Produktivitas peningkatan usaha ternak sapi bali oleh peternak non transmigran sebesar $36 \%$ pertahun lebih tinggi dibandingkan dengan produktivitas peningkatan usaha ternak sapi bali oleh peternak transmigran yakni sebesar $24 \%$ pertahun.

2. Produktivitas usaha secara keseluruhan dipengaruhi oleh lama usaha beternak, umur peternak, jumlah tenaga kerja terlibat, pendidikan formal, luas lahan pertanian, dan jenis pekerjaan Faktor yang berpengaruh positif terhadap produktivitas usaha ternak adalah pengalaman beternak, tenaga kerja setara pria, tingkat pendidikan, dan luas lahan.

\section{DAFTAR PUSTAKA}

Abidin, A. dan D. Simanjuntak. 1997. Ternak Sapi Potong. Direktorat Jenderal Peternakan. Jakarta.

Abidin, Z. 2006. Penggemukan Sapi Potong. Agromedia Pustaka. Jakarta.

Adiwilaga, A. 1982. Ilmu Usaha Tani. Penerbit Alumni. Bandung.

BPS. 2011. Sulawesi Tenggara dalam Angka. Badan Pusat Statistik Provinsi Sulawesi Tenggara. Kendari.

Chamdi, A.N. 2003. Kajian profil sosial ekonomi usaha kambing di Kecamatan Kradenan Kabupaten Grobongan. Prosiding Seminar Nasional Teknologi Peternakan dan Vetereiner. Bogor 2930 September 2003. Bogor. Puslitbang Peternakan Departemen Pertanian.

Djaafar, S. 2007. Faktor-faktor yang mempengaruhi dan strategi pengembangan usaha ternak sapi potong rakyat di Kabupaten Banggai Propinsi Sulawesi Tengah. Tesis. Fakultas Peternakan. Sekolah Pascasarjana Universitas Gadjah Mada. Yogyakarta.
Fauzia, L., dan H. Tampubolon. 1991. Pengaruh Keadaan Sosial Ekonomi Petani Terhadap Keputusan Petani Dalam Penggunaan Sarana Produksi. Universitas Sumatera Utara Press. Medan.

Fatah, A. M. 2008. Teknis Pemeliharaan Sapi Potong.(online). http://go-organik2010.blogspot.com/2008/08/teknis pemeliharaan-sapi-potong.html. [Diakses 21-05-2009].

Fatati. 2001. Perilaku petani peternak dalam diversifikasi tanaman kelapa sawit dengan sapi potong di daerah transmigrasi sungai bahar Kabupaten Muaro. Jurnal Ilmu-Ilmu Peternakan. Vol.4 (2).

Gunawan, D. Pamungkas dan Laffandhy. 1998. Sapi Bali. Potensi, Produktivitas dan Nilai Ekonomi. Kanisius. Yogyakarta.

Hadi, P.U. dan N. Ilham. 2000. Peluang pengembangan usaha pembibitan ternak sapi potong di indonesia dalam rangka swasembada daging 2005. Makalah Dipresentasikan dalam Pertemuan Teknis Penyediaan Bibit Nasional dan Revitalisasi UPT TA. 2000. Direktorat Perbibitan, Direktorat Jenderal Bina Produksi Peternakan. Jakarta. 11-12 Juli 2000.

Hadi, P.U., A. Thahar, N Ilham, and B. Winarso, 2002. A Progress report summary: analytic framework to facilitate development of Indinesia's beef industry. Paper presented at the "Routine seminar". Center for Agro socio Economic Research and Development. Bogor, 8 Maret 2002.

Hadi, P.U. dan T.B. Purwantini. 1991a. Kajian pola produksi pertanian lahan kering di Kabupaten Bima Nusa Tenggara Barat. Laporan Hasil Penelitian. Pusat Penelitian Sosial Ekonomi Pertanian, Bogor. Hlm 121. 
Hardjosubroto, W. 1992. Pola Pembiakan dan Output Sapi Potong. DPPM. Universitas Gadjah Mada. Yogyakarta.

Hardjosubroto, W. 1994. Aplikasi Pemuliabiakan Ternak di Lapangan. Grasindo. Jakarta.

Hartono, B. 2005. Curahan tenaga kerja keluarga di usaha ternak sapi perah kasus di Pandesari Kecamatan Pujong Kabupaten Malang Jawa Timur. Buletin Peternakan. Fakultas Peternakan Universitas Gadjah Mada. Yogyakarta.

Hastian. 2010. Analisis efesiensi pengolahan dan pemasaran hasil usaha tani kelapa di Kabupaten Bombana. Majalah Ilmiah Agriplus. Vol. 20 (1).

Hartoyo. 1995. Struktur pendapatan penjual dan jagal sapi di Kotamadya Yogyakarta. Skripsi. Fakultas Peternakan Universitas Gadjah Mada. Yogyakarta.

Hernanto, F. 1996. Ilmu Usaha Tani. Penerbit Swadaya. Jakarta.

Iksan, LM. 2009. Angka kelahiran sapi bali pada daerah transmigrasi dan non transmigrasi di Kabupaten Muna. Skripsi. Jurusan Peternakan Fakultas Pertanian Universitas Haluoleo. Kendari.

Kuswaryan, S., S. Rahayu, C. Firmansyah, dan A. Firman. 2004. Manfaat ekonomi dan penghematan devisa impor dari pengembangan peternakan sapi potong lokal. Jurnal Ilmu Ternak. Vol.4(1): 41-46.

Mersyah, R. 2005. Desain sistem budi daya sapi potong berkelanjutan untuk mendukung pelaksanaan otonomi daerah di Kabupaten Bengkulu Selatan. Disertasi. Sekolah Pascasarjana. Institut Pertanian Bogor. Bogor.
Mubyarto, 1991. Pengantar Ekonomi Pertanian. LP3ES. Jakarta.

Prasetyo, T. 1994. Perbaikan manajemen dan teknologi penggemukan sapi di lahan kering das jratunseluna dan brantas bagian hulu. Majalah Ilmiah Universitas Semarang Edisi Khusus. Hlm. 16-23.

Prawirokousumo, Y.B. 1991. Ilmu Usahatani. BPFE. Yogyakarta.

Rumalutur, T. 2001. Peningkatan keluarga petani transmigran dan petani penduduk asli di Desa Sagron-Dosai Kecematan Sentani Kabupaten Jaya Pura. Universitas Cendrawasih Jaya Pura. (online). http://www.itb. centrallibrary.ac.ib. (Diekses 2011).

Rustijano, S. 2005. Potensi pemasaran ternak sapi potong di Kecamatan Srandakan Kabupaten Bantul Provinsi Daerah Istimewa Yogyakarta. Balai Pengkajian Teknologi Pertanian Yogyakarta. Yogyakarta.

Sani, L. A. 2010. Faktor-faktor yang mempengaruhi curahan tenaga kerja keluarga transmigran dan lokal pada pemeliharaan sapi potong di Kabupaten Konawe Selatan. Majalah Ilmiah Agriplus. Vol. 20 (1) : 48-56.

Simanjuntak, P.J. 2001. Pengantar Ekonomi Sumberdaya Manusia. Fakultas Ekonomi Universitas Indonesia. Jakarta.

Siswati, L. dan A. Mutahar. 2005. Analisis faktor-faktor yang mempengaruhi pendapatan usaha keluarga transmigran peternak sapi di Kecamatan Pamenang Kabupaten Merangin. Jurnal Peternakan. Vol. 2 (1).

Soekartawi, A. Seoharjo, Dillon, J.L. Hardaker, J.B. 1986. Ilmu Usahatani dan Penelitian Untuk Perkembangan Petani Kecil. UI-Perss. Jakarta. 
Soehardjo dan D. Patong. 1984. Sendi-Sendi Pokok Ilmu Usaha Tani. Universitas Hasanudin. Ujung Pandang.

Soekardono. 2009. Ekonomi Agribisnis Peternakan Teori dan Aplikasinya. Akademika Pressindo. Jakarta.

Subandi dan Zubachtirodin. 2004. Prospek pertanaman jagung dalam produksi biomas hijauan pakan. prosiding seminar nasional. Pemberdayaan Petani Miskin di Lahan Marginal Melalui Teknologi Tepat Guna. BPTP NTB. Puslitbangsosek. Badan Litbang Pertanian.

Sudarmanto, B. 2005. Produktivitas tenaga kerja keluarga dalam pemeliharaan sapi perah di Kecamatan Getasan Kabupaten Semarang. Tesis. Fakultas Peternakan. Sekolah Pascasarjana Universitas Gadjah Mada. Yogyakarta.

Sukmawati. 2011. Identifikasi saluran dan margin pemasaran sapi bali di Pulau Kabaena Kabupaten Bombana. Skripsi. Jurusan Peternakan. Fakultas Pertanian. Universitas Haluoleo. Kendari.

Sunandar, N. 2005. Analisis intensi ekonomi, keunggulan komparatif, dan keunggulan kompetitif usaha ternak sapi potong di Kabupaten Gunung
Kidul. Disertasi. Program Studi Ekonomi Pertanian. Sekolah Pascasarjana. Universitas Gadjah Mada. Yogyakarta.

Suratiyah, K. 2006. Ilmu Usaha Tani. Penebar Swadaya. Jakarta.

Syamsu, A.J., L.A. Sofyan, K. Mudikdjo, dan G. Said. 2003. Daya dukung limbah pertanian sebagai sumber pakan ternak ruminansia di Indonesia. Wartazoa Vol.13(1): 30-37.

Talib, C. 2009. Sapi bali di daerah sumber bibit dan peluang pengembangannya. Bogor. (online). http://peternakan.litbang.deptan.go.id /publikasi/wartazoal wazo1232.pdf. (Diakses 25 Maret 2009).

Talib, C. 2001. Pengembangan sistem perbibitan sapi potong nasional. Wartazoa Vol.11(1): 10-19.

Tulle, D. R. 2005. Analisis motivasi dan pendapatan pada usaha pemeliharaan ternak babi skala rumah tangga di Kota Padang. Tesis. Program Pascasarjana. Universitas Gadjah Mada. Yogyakarta. 